\title{
Economic Strategy: Correlation between Macro and Microeconomics on Income Inequality in Indonesia
}

\author{
Agus SALIM ${ }^{1}$, Andi RUSTAM ${ }^{2}$, Haeruddin HAERUDDIN ${ }^{3}$, Asriati ASRIATI ${ }^{4}$, \\ Aditya Halim Perdana Kusuma PUTRA ${ }^{5}$
}

Received: May 06, 2020 Revised: May 31, 2020 Accepted: July 09, 2020

\begin{abstract}
This study sees a critical gap in the previous body of research, which it seeks to fill; the disclosure of the unemployment ratio correlation has only been measured by the level of economic growth. This study is to add investment variables and government expenditure variables that objectively aim to measure the level of effectiveness in handling the unemployment ratio, which is then a measurement of the effectiveness of unemployment. Economic growth is measured by its impact on income inequality through empirical, conceptual relationships as a critical review and economic strategy for the future. The research uses secondary data on Indonesian macro and microeconomics since 2003-2018, then testing uses a quantitative approach to correlation, regression, and scatterplot. The results of this study show correlations between variables, and volatiles on the graphs show a similar trend. In other words, variables are bound together and support each other. The strategy of prioritizing the scale of government expenditure and investment to reach the target is the primary concern, so that the economic cycle can be optimal and equipped to face the possibility of an economic recession in the future. Many factors cause complex income inequality, though investment does not show a correlation to income inequality.
\end{abstract}

Keywords: Investment, Government Expenditure, Economic Growth, Unemployment, Inequality Income

JEL Classification Code: D04, D31, D6

\section{Introduction}

Indonesia is the largest country in Southeast Asia, where achievements have been significant in terms of reducing

${ }^{1}$ First Author and Corresponding Author. Associate Professor, Department of Islamic Economics, Faculty of Economics \& Business, Universitas Muhammadiyah Makassar, Makassar, Indonesia [Postal Address: No.259, Sultan Alauddin Street, Makassar City, South Sulawesi 90221, Indonesia] Email: as.unismuh@gmail.com

${ }^{2}$ Associate Professor, Faculty of Economics, Department of Management, STIE YPUP, Makassar Indonesia.

${ }^{3}$ Associate Professor, Faculty of Economics \& Business, Department of Taxation, Universitas Muhammadiyah Makassar, Makassar Indonesia.

${ }^{4}$ Associate Professor, Faculty of Economics \& Business, Department of Economics Development Studies, Universitas Muhammadiyah Makassar, Makassar Indonesia.

${ }^{5}$ Assistant Professor, Department of Management, Faculty of Economics and Business, Universitas Muslim Indonesia. Email: adityatrojhan@gmail.com

(c) Copyright: The Author(s)

This is an Open Access article distributed under the terms of the Creative Commons Attribution Non-Commercial License (http://Creativecommons.org/licenses/by-nc/4.0/) which permits unrestricted noncommercial use, distribution, and reproduction in any medium, provided the original work is properly cited. poverty levels since 1999 (Tjoe, 2018). Indonesia is also the fourth most populous country in the world after China, India, and the United States. (Putra, Said, \& Hasan, 2017). However, the problem of reducing levels of poverty has not been accompanied by a significant reduction in income inequality. The data show that there is still income inequality in Indonesia, where economic growth is enjoyed by the wealthiest part of the communities, which accounts for $20 \%$ of the population (www.worldbank.org, 2015), even income inequality between rich and poor people is still relatively high. Inequality is reflected in the accumulation of wealth enjoyed by only a handful of people in Indonesia. The country is ranked the fourth highest out of nine countries (Russia, Thailand, India, Brazil, China, United States, South Africa, and Mexico). $49,3 \%$ of the national wealth is owned by only $1 \%$ of the citizens (Widyanita, 2017). Indonesia's economic growth is the third-fastest among other G-20 countries; statistical figures from 2000 to 2017 show Indonesia's GDP (Gross domestic product) per capita increases $4 \%$ every year after China and India (Tjoe, 2018).

The Indonesian Gini ratio index also increased from 30 in the 90s to 39 in 2017 (See. Figure 1). However, 


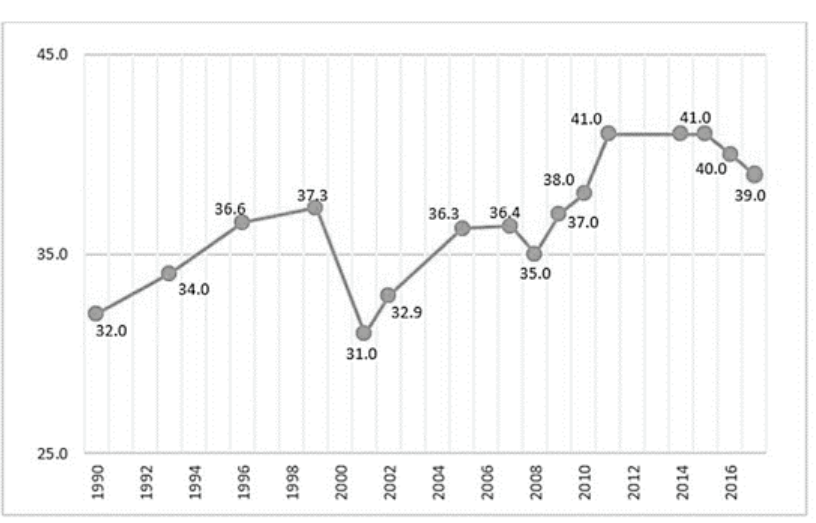

Figure 1: Gini Ratio Indeks

Indonesia's increasing economic growth is not in line with income distribution, triggering inequality between citizens. Inequality of income that moves slowly with economic growth is triggered by some fundamental aspects, namely, educational qualifications, labor market, and labor skills, which also increase (www.worldbank.org, 2015). As regards the relationship between unemployment rate and income inequality Gächter et al. (2017) and Shao et al. (2016) state that strong correlations can occur if the unemployment rate can be reduced, which will cause income inequality to be also suppressed. On the contrary, there is the view that there is no significant correlation between income inequality driven by economic growth and the unemployment rate (Sadiku, Ibraimi, \& Sadiku, 2015; Ghoshray, Ordóñez, \& Sala, 2016).

The efforts of the Indonesian government to trigger economic growth through the stimulation of funds for public-service allocation and welfare (e.g., education and health) also experienced an increase, with the hope that there would be no vacancy for skilled labor, which would have an impact on unemployment. Therefore, from Indonesia's State Budget (APBN) in 2018, funding of IDR347.4 trillion has been allocated to meet the public-service sector; IDR157.6 trillion went to the social protection sector and IDR143.1 trillion went for the education sector (www.kemenkeu.go.id, 2018). Efforts have been committed to increase the state budget in the public sector to support efforts to accelerate a quality economic growth by strengthening the economic impetus. Because another impact created by unemployment is income inequality, it can result in the inability of the community to meet the essential aspects of basic needs and services (i.e., food, health, and education) (Ram, 1982; Ram, 1992; Di Domenico \& Fournier, 2014; Dinh, 2020; Luong et al., 2020; Nguyen, 2020).

In Indonesia, the government's policy to overcome the problem of income inequality is pursued through several strategic steps such as improving public services, strengthening social protection, (Gächter et al., 2017), training for workers, providing employment, and raising public awareness through tax collection (www.worldbank. org, 2015). Gächter et al., (2017), using the Equilibrium Theory approach, explains that differences in the socioeconomic status have an impact on welfare. However, there are gaps in the different study results put forward by Han, Zhao, and Zhang (2015), which states that the Gini ratio and total income per capita have no significant impact on income inequality.

Therefore, efforts to reduce income inequality through the approach to reduce the unemployment in Indonesia, via measures to increase investment at the micro-level, are expected to foster community business enthusiasm so that regional and national economic growth can be realized (Halvarsson, Korpi, \& Wennberg, 2018). Indonesia's State Budget Posture of 2018, which reflects the government investment sector, emphasizes aspects of national infrastructure development where the budget allocation reaches IDR 410.4 trillion to the ministry of public works and public housing (PUPR), the ministry of transportation, the General Allocation Fund (DAU), the Indonesian government investment PMN (State Capital Participation), and LMAN (State Asset Management Institute). It is where investment policies in the infrastructure sector are to support the center of economic growth, the main path of logistics, and integration of capital to encourage the development of strategic areas. The Indonesian government investment financing increased from IDR59.7 trillion in 2017 to IDR65.7 trillion in 2018 (www.kemenkeu.go.id, 2018).

Investment in Indonesia itself is governed by various governmental regulations (i.e., Article No. 25, 2007, Article No. 37 of 1999, Government regulation No. 8 of 2007, Article No. 1 of 2004). The type of investment also varies from investment in the form of bonds, direct investment, investment in the development of general services, services, and financing of community business activities, and investment in the event of BUMN and BUMD (State-owned enterprises, Local-Owned enterprises). The investment provides an essential role as the primary foundation to encourage a country's economic growth (Afidchao et al., 2014; Szkorupová, 2014; Mihaiu \& Opreana, 2013; Trejo García et al., 2017; Khodeir, 2016; Guerrazzi, 2015; Sadikova, Faisal, \& Resatoglu, 2017). Furthermore, according to a statement, the economic growth aspired to be pursued through productive investments both short and long term (Kudasheva et al., 2015; Halvarsson et al., 2018). On the other hand, in empirical evidence in several studies, there are different results shown by several studies (Strat et al., 2015; Khodeir, 2016; Ghoshray et al., 2016), which say that investment has no impact on economic growth. There are differences in the results of studies mediated by differences in government decision-making processes contained in government policies that cover investments. So, it can be 
stated that government policy indeed plays a vital role in supporting a conducive and adequate investment climate (Roşoiu, 2015).

Furthermore, regarding the subject of this study, amid the opportunities that exist and given that the world economic arena is moving to Asia, Indonesia has some great opportunities to realize an investment climate, both at the macro and micro levels, so that it provides hope for economic growth in the long run. One of them is an investment in infrastructure, and investment in the creative and digital economy (Sukarno, 2019). Nevertheless, the classic obstacle to investment in Indonesia continues to roll; one of the main hurdles in investing is the flow of bureaucracy and licensing, whose coordination is considered sub-optimal between the center and the regions (www.republika.co.id, 2018; www.kemenprin.go.id, 2018), weaknesses in meeting the energy supply needed by industry, and the concentration of investment distribution, which only focuses on one particular area (www.nasional.kontan.co.id, 2010). Therefore, the Indonesian government's effort to increase economic growth in addition to investment, is through the effectiveness of government expenditure.

Reflecting on the 2018 Indonesian State Budget, total national expenditures were IDR2,220.7 trillion (Expenditure for sector ministries and institutions), IDR847,4 trillion (General allocation fund to the province), IDR766,2 trillion (Village fund), and non-ministerial and institutional expenditure, IDR607.1 trillion (www.kemenkeu.go.id, 2018). The purpose of the state expenditures is to synergize social protection programs and sharpen social assistance, one of which is in the aspects of education and health. In this regard, the dominant state expenditure policy in the education and health sector has been proven empirically able to address social inequalities directly or indirectly. (Lavrinovicha et al., 2015; O'Campo et al., 2015; Shen et al., 2018; Kim, 2016). In Indonesia alone, the distribution of the highest unemployment rate by province released by the Central Statistics Agency (BPS) recorded that there were 131.55 million people in the workforce, of which 124.54 million were employed, and the remaining 7.01 million were unemployed. In Indonesia, the open unemployment rate reached 5.33 percent, decreasing by 0.28 percent from 2016 .

Theoretical exposures and disclosure of factual phenomena regarding the relationship of investment, government expenditure on economic growth to overcome unemployment and income inequality gave birth to the main ideas related to the various suitability and mismatch between theories, facts, and the results of empirical testing. This study sees a critical gap in previous studies: the disclosure of the unemployment ratio correlation is only measured by the level of economic growth. So, the novelty developed in this study is to add investment variables and government expenditure variables to measure the level of effectiveness to deal with the unemployment. It is then a measurement of the effectiveness of unemployment, and economic growth is measured by its impact on income inequality through empirical, conceptual relationships. See Figure 2 for a critical review.

\section{Literature Review and Hypothesis Development}

\subsection{Macroeconomics Perspective}

In macroeconomic theory, human development (HDI) depends on two main aspects, namely, economic growth and decreasing inequality between populations (Sargent, 2009; Davidson, 2011). The development of a dignified human index requires government efforts in terms of an even increase in the education sector because income inequality is caused, among other factors, by the high unemployment rate. The research "Influence of Education on Unemployment Rate and Incomes of Residents" found that investment in human development starts from improving education to better meet basic human needs, so that the link between investment and government expenditure (government expenditure) through the education sector directly impact income inequality for the productive workforce (Lavrinovicha et al., 2015; www. bbc.com, 2014). In 2016, research results from Lavrinovicha et al. (2016) and Kudasheva, Kunitsa, and Mukhamediyev (2015) state that social inequality caused by income inequality comes from unequal access to education. Income inequality, which has a direct effect on high unemployment, will also have an impact on the difference in health and social welfare (Kim, 2016; Shao et al., 2016). So, that the hope to be achieved is an equal distribution of all aspects to prevent inequality in the community (Gächter et al., 2017).

The measurement of income inequality is closely related to the economic growth potential of a region (Goschin, 2015). Many researchers have examined the causal relationship between the two from various research perspectives (Hassan, Zaman, \& Gul, 2015; Lyubimov, 2017). The Kuznets Theory states that reducing income inequality can be pursued by the government through comprehensive, tested government policy. In line with Blundell et al. (2018) and Birčiaková, Stávková, and Antošová (2014), the inequality theory approach with the comparative study approach further states that in addition to government policy, the constitutional arrangement and governance patterns also contribute significantly in terms of decreasing or increasing income inequality trends.

In terms of government policy, the source of state revenue is primarily sourced from tax and non-tax revenue (PNBP). Policies pursued through improving the investment climate in the business world, include providing incentives and optimizing economic potential and tax reform measures. One of which is the application of tax amnesty, Automatic 
Exchange of Information (AEol), which aims to increase the tax base to prevent the practice of tax avoidance and tax erosion, taxpayer compliance, tax holidays, via data and taxation information systems as well as service improvement and organizational effectiveness in the scope of taxation. Other policies pursued are also through improving regulations, increasing services and management, optimizing PNBP and improving public services (www. kemenkeu.go.id, 2018).

Apart from that, the policy on the aspects of government expenditure, which aims to support the administration of government, is pursued through the administration of government policies to maintain the welfare of the government apparatus and the effectiveness of the bureaucracy. The anticipation of risks related to government expenditure policies is also translated into anticipating economic uncertainty through the support of fiscal risk reserves and disaster mitigation. Appropriate state expenditure becomes a goal aspiration based on efficiency and effectiveness, which can also have a significant impact on reducing the ratio of social inequality and the unemployment rate through the allocation of funds that are more coherent in terms of investment (Raišienè, Bagdonienè, \& Bilan, 2014; Li \& Hu, 2015; Bouwmeester \& Scholtens, 2017).

Furthermore, the problem in macroeconomic growth is the problem of unemployment, which will have a universal impact on improving the quality of life; this can also be tangent to the economic growth of a region or even a country. This causality is very closely related, given that labor is one of the essential aspects of classical economic production (man, capital, and land). The main unemployment problem is identified by the role of adequate education to shape the demand for skilled workers in the labor market (Kudasheva et al., 2015), so that an essential aspect in government policy issues requires the education aspect as one of the principal investments to welcome skilled workers to reduce unemployment and overcome income inequality (Halvarsson et al., 2018). This opinion is in line with what is happening, where the Indonesian Central Statistics Agency released the unemployment rate of 7 million people, dominated by high school / vocational school graduates (Andreas, 2018).

The leading causes of high unemployment are also low income and low socioeconomic consumption (Guerrazzi, 2015; Gächter et al., 2017). Government policy in terms of investment in the sectors expanding employment becomes heavy work that requires the participation of many parties. The employment status shown in Figure 3 show that, in 2017, a total of 52 million people -42.97 percent of the population - worked in the formal sector (permanent workers/ employees). Previous studies (Adriana, 2014; Roşoiu, 2015; Sadiku et al., 2015) in the Macedonian Country concluded that there was no correlation between economic growth and the unemployment ratio. Other studies, with limitations in the disclosure and testing of variables in measuring the unemployment rate, also showed these results (Ghoshray et al., 2016; Khodeir, 2016; Strat et al., 2015). All state that foreign investment does not affect the reduction of the unemployment rate.

Disparities between regions are prevalent in the economic activities. Disparities between areas occur because of differences in the natural resources and in demographic conditions found in each area. This difference makes the ability of a region to drive the development process unique to that region. Therefore, in each part of the country, there are usually developed regions (Developed Region) and underdeveloped regions (Underdeveloped Region) (Hidayat, 2014). Inequality between regions was raised by Douglas C. North in his analysis of the Neo-Classical Growth Theory. In this theory, he raised the prediction of the relationship between the level of national economic development of a country and the imbalance of development between regions. This hypothesis was later known as the Neo-Classical Hypothesis.

\subsection{Prior Research and Conceptual Framework}

Increased investment is believed to have a contribution as a lever towards the movement of the economic development of a nation. In macroeconomics, investment also acts as one component of national income, Gross Domestic Product (GDP). The effect of investment on a country's economy is reflected in the country's national income, the investment is positively correlated with GDP; in general, it can be said, if investment rises, then GDP tends to increase. Or conversely, if investment falls, GDP tends to decrease. Some economists consider investment formation to be an essential factor that plays a strategic role in a country's economic growth and development. When entrepreneurs, individuals or the government invest, there will be a certain amount of capital invested, and there are some purchases of goods that are not consumed, but are used to produce goods and services in the future. Even economic growth that can result in economic inequality in the community can also be minimized.

The results of the study reveal the existence of a significant influence between investment and economic growth (Afidchao et al., 2014; Szkorupová, 2014; Mihaiu \& Opreana, 2013). The results of the empirical study discussed earlier also reveal the same thing, namely, the existence of a positive relationship between investment and income inequality (Kudasheva et al., 2015; Halvarsson, Korpi, \& Wennberg, 2018). Equitable economic growth, starting from positive investment, is useful so that it can have a significant impact on reducing the unemployment ratio (Trejo García et al., 2017; Guerrazzi, 2015; Sadikova et al., 2017; Li \& $\mathrm{Hu}$, 2015; Khodeir, 2016; Elshamy, 2013) but the results of research from (Sadiku et al., 2015; Strat et al, 2015; 
Ghoshray et al., 2016) It was revealed that there was no positive correlation between economic growth and declining unemployment rates.

The utilization of government spending is optimized both in supporting the implementation of government programs. Productive state expenditure will encourage better economic growth through productive and beneficial expenditure activities that are both short and long term, such as infrastructure development to facilitate modes of transportation and economic activities. On the other hand, significant economic growth will drive down unemployment ratios through business activities, both on a macro and micro-scale. Unemployment that can be reduced will have a significant effect on decreasing the income inequality ratio. This opinion is in line with the results of research (Lavrinovicha et al., 2015; Kim, 2016; Raišienè et al., 2014; Li \& Hu, 2015; Bouwmeester \& Scholtens, 2017; O’Campo et al., 2015; Bouwmeester \& Scholtens, 2017; Shen et al., 2018; Mihaiu \& Opreana, 2013; Candemir \& Zalluhoglu, 2011; Nguyen, 2019). However, there are different opinions expressed by (Adriana, 2014; Roşoiu, 2015) However, there are different opinions expressed (Han et al., 2015) arguing that government spending with a different constitutional system also had a significant impact on income inequality and economic growth.

\section{Research Design and Methods}

\subsection{Data and Materials}

The type of data used in this study are quantitative data with secondary data types in Indonesia, which are summarized from thirty-four provinces in the period 2003 - 2018, which includes data on the level of development of government investment (i.e., realization of investment in domestic investment and realization of foreign investment capital). Government expenditure data include nonministerial and institutional expenditures, regional transfer funds, balancing funds consisting of profit-sharing funds, general allocation funds, special allocation funds, nonphysical special allocation funds, local incentive funds, special autonomy funds and privileged funds, and village funds. There are also economic growth data, unemployment rate data, and data on income inequality ratios. The data materials are attached in Appendix.1.

\subsection{Measurement and Research Design}

The measurement value equalization model requires several stages, such as variable investment and government expenditure, namely, data transformation using the Log10 compute variable using SPSS. After transforming the value variable, the test continues with testing the hypothesis through direct and indirect testing (See Figure 2) using SmartPLS. The feasibility testing function of the model ignores the principles of normality, validity, and reliability, given that the nature of the data used is secondary. Furthermore, at the stage of testing the hypothesis of significance limits $(p<0.05)$ the Sobel-test method is used. Correlation analysis between variables uses the Spearmen Correlations method and a scatter plot graph.

\section{Results and Discussion}

\subsection{Correlation}

This sub-section explains the correlation between related macroeconomic variables, the spearman correlation method, and scatterplot graphics (See Appendix 2). Economic growth variables have a positive, but not significant correlation $(\alpha=$ 0.320 or $32 \%$; sig. Level $0.228>0.05$ ). It is the same as stating the correlation between government expenditure on economic growth $(\alpha=0.343$ or $34.3 \%$; sig. Level $0.193>0.05)$. On the other hand, economic growth is positively and significantly correlated with income inequality (economy $(\alpha=0.653$ or $65.3 \%$; sig. Level $0.006<0.01$ ), and a negative correlation does not relate directly between economic growth with the

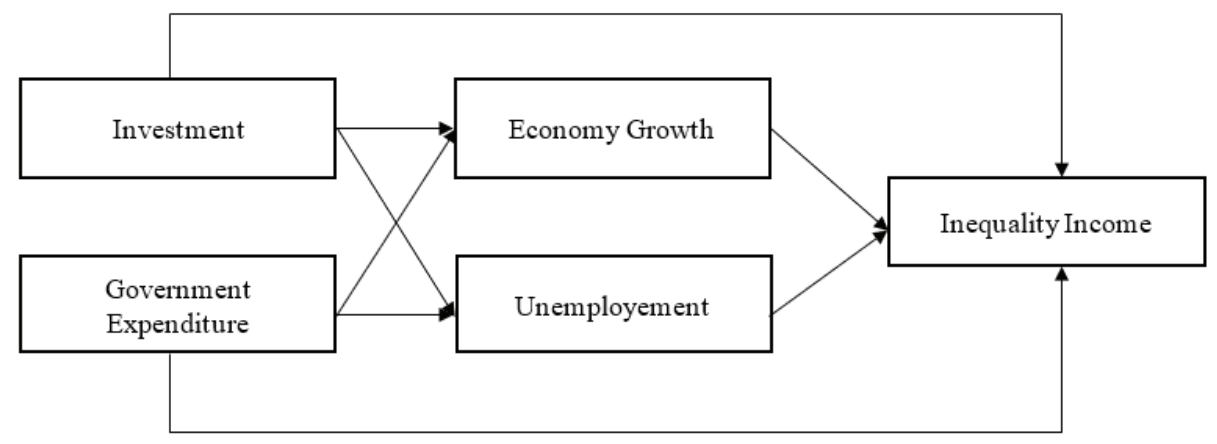

Figure 2: Conceptual Framework 
unemployment rate $(\alpha=-0.370$ or $-37 \%$; level $0.159>0.05)$. Then, the correlation between the unemployment rate, which will have an impact on income inequality, has a positive and significant correlation ( $\alpha=0.637$ or $63.7 \%$; sig. Level 0.008 $<0.01$ ). Investment also has the impact and relationship to the magnitude of the unemployment rate, although indirectly $(\alpha=-0.907$ or $90.7 \%$; sig. Level $0.000<0.01)$. Likewise, the impact caused by expenditure on the magnitude of income inequality levels is positively and significantly correlated $(\alpha=0.713$ or $71.3 \%$; sig. Level $0.002<0.05$ ) The most significant correlation is shown in the relationship between government expenditure and investment $(\alpha=0.940$ at au $94 \%$; sig. Level $0,000<0.01)$.

\subsection{Regression}

Appendix 4 illustrates the direct effect of variables. The role of economic growth and government expenditure as an effort to reduce inequality income figures has a positive and significant impact. The low level of unemployment has no positive and significant impact on low-income inequality. However, there are different results, and investment has no significant effect on income inequality.

In tests involving the mediation of economic growth and unemployment, the role of government expenditure and investment, which is higher than the data observation period and then subsequently mediated by economic growth variables, will reduce the problem of income inequality significantly Conversely, some mediation test results using the unemployment variable with the Sobel test showed no significant effect. Figure 3 graphically explains the correlation between variables. The volatile model is formed following a similar pattern; for example, the trend of economic growth and the magnitude of the level of government expenditure are rising or falling due to movement in the unemployment rate curve and income inequality.

\subsection{Discussion}

\subsubsection{Indonesia in Macroeconomics Perspective}

The results of studies and testing of data illustrated by graphs and regression models show some positive, significant, and insignificant influences. Appendix 2 depicts volatiles with similar patterns. This means that the rise, fall, and intersection of one variable through the graph will have an impact on other variables systematically. Dissecting Indonesia's statistics in 2019, the central government expenditure sector (See. Table 1) (e.g., ministries and official expenditure and non-official expenditure and official expenditure) is the sector that absorbs the most significant budget (i.e., $63.2 \%$ for $2017 ; 65.4 \%$ for 2018 and $66,4 \%$ for 2019) where the aims and objectives of ministries or nonofficials and non-expenditure are intended for guarantees and facilities as well as health and education infrastructure. Then, the second most significant Indonesian government expenditure is in the sector of expenditure for regions (i.e., transfers to areas, balances funds, regional incentive funds, and special autonomy privilege functions, village funds). To finance such a large amount of government expenditure, the largest source of income certainly comes from taxes and revenue from natural resources. However, the amount of spending that is not balanced with the level of income makes the trade balance produces a budget deficit.

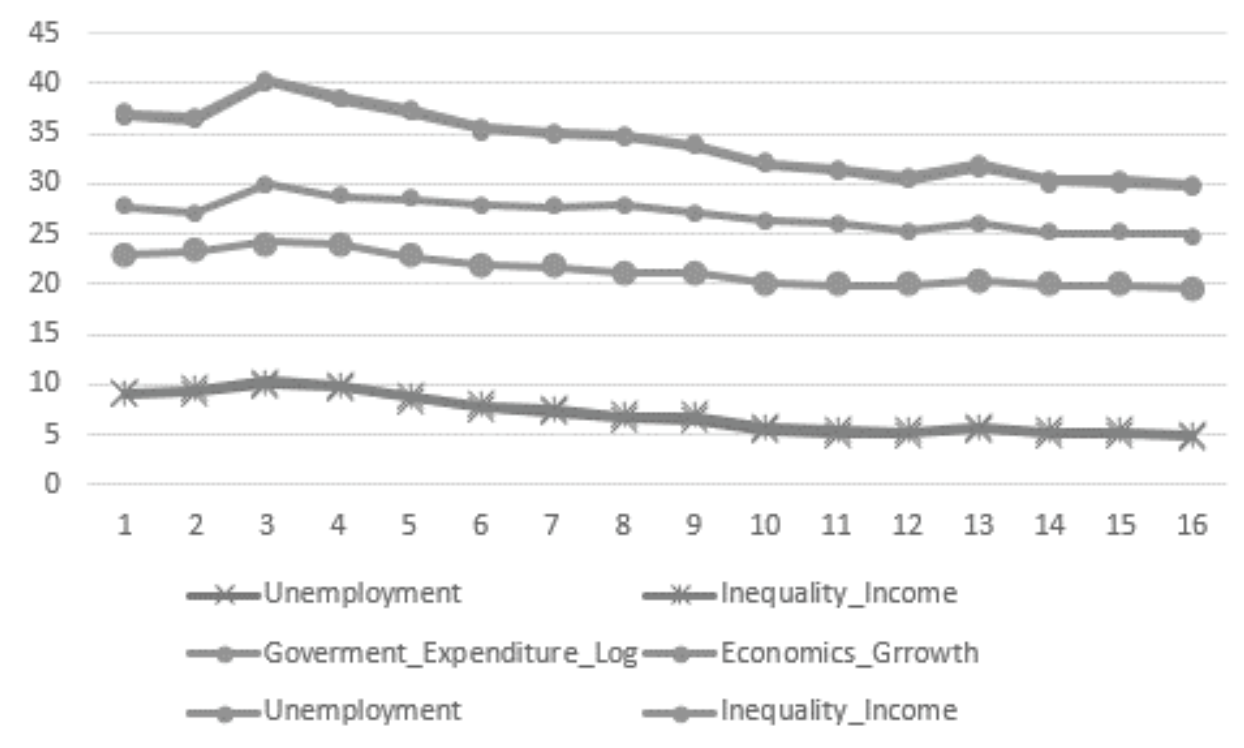

Figure 3: Correlation and Tren Model 


\subsubsection{Relevance between Macro and Microeconomics}

The graph shown in Appendix 2 provides clear evidence that income inequality in Indonesia is influenced by a variety of factors, in particular, this study shows how the role of community dependents on government expenditure. The geological typology of Indonesia as an archipelago (total area $1,916,862.20 \mathrm{~km} 2$ with the total of 4,108 islands) also

Table 2: Budget Percentage Allocation of Central Government Expenditures by Function

\begin{tabular}{|l|c|c|c|}
\hline \multicolumn{1}{|c|}{ Function } & $\mathbf{2 0 1 7}$ & $\mathbf{2 0 1 8}$ & $\mathbf{2 0 1 9}$ \\
\hline $\begin{array}{l}\text { General Public } \\
\text { Service }\end{array}$ & 27,0 & 30,0 & 31,7 \\
\hline Defence & 8,2 & 7,4 & 6,6 \\
\hline $\begin{array}{l}\text { Public order and } \\
\text { Safety }\end{array}$ & 9,2 & 9,3 & 8,7 \\
\hline Economics Affairs & 23,6 & 23,1 & 23,8 \\
\hline Environment & 0,9 & 1,1 & 1,1 \\
\hline $\begin{array}{l}\text { Housing and } \\
\text { Community Amenities }\end{array}$ & 2,3 & 2,2 & 1,6 \\
\hline Health & 4,7 & 4,5 & 3,8 \\
\hline Tourism and Culture & 0,4 & 0,5 & 0,3 \\
\hline Religion & 0,7 & 0,7 & 0,6 \\
\hline Education & 10,9 & 10,1 & 9,3 \\
\hline Social protection & 12,0 & 11,2 & 12,3 \\
\hline In Million Rupiahs & 1.315 .526 & 1.454 .494 & 1.634 .340 \\
\hline
\end{tabular}

triggers various income inequality issues from the aspect of inflation and price imbalances against market demand. On the other hand, dependence on government expenditure through ministries and officials or non-expenditure and the largest source of income from the public tax sector and the income derived from natural resources can be seen from the positive and negative sides of how the production process, distribution of goods, and services with long chains can only be enjoyed by the community. The amount of government expenditure whether related to the ministries or not and officials or non-sectors is highly dependent on unique and optimal aspects of good corporate governance; errors and inaccuracies in the GCG process can trigger unequal income inequality issues given Indonesia's vast demographic area. The magnitude of the level of government expenditure (Government expenditure volatile) also has an impact on the level of unemployment that occurs when National non-tax revenue is sourced from natural resource (oil, gas, mining, forestry, fishery). Because if studied in-depth, for example, in the mining sector, forestry and fishery, economic-driving factors in the industry are predominantly derived from the SES BE group (see Figure 4 and Appendix 3). While revenue from the Ministries (SOE's) sector only contributed a third out of five domestic revenue sources.

Figure 4 illustrates the placement of workers in the primary industry, and there are three employment statuses that are highly dependent on government regulations and the amount of government expenditure (i.e., temporary workers, casual workers, and family workers). In contrast, ownaccount workers are very reliant on government regulations and conditions of economic growth. Employees with a significant amount can be assumed to burden national income

\section{Employment Status}
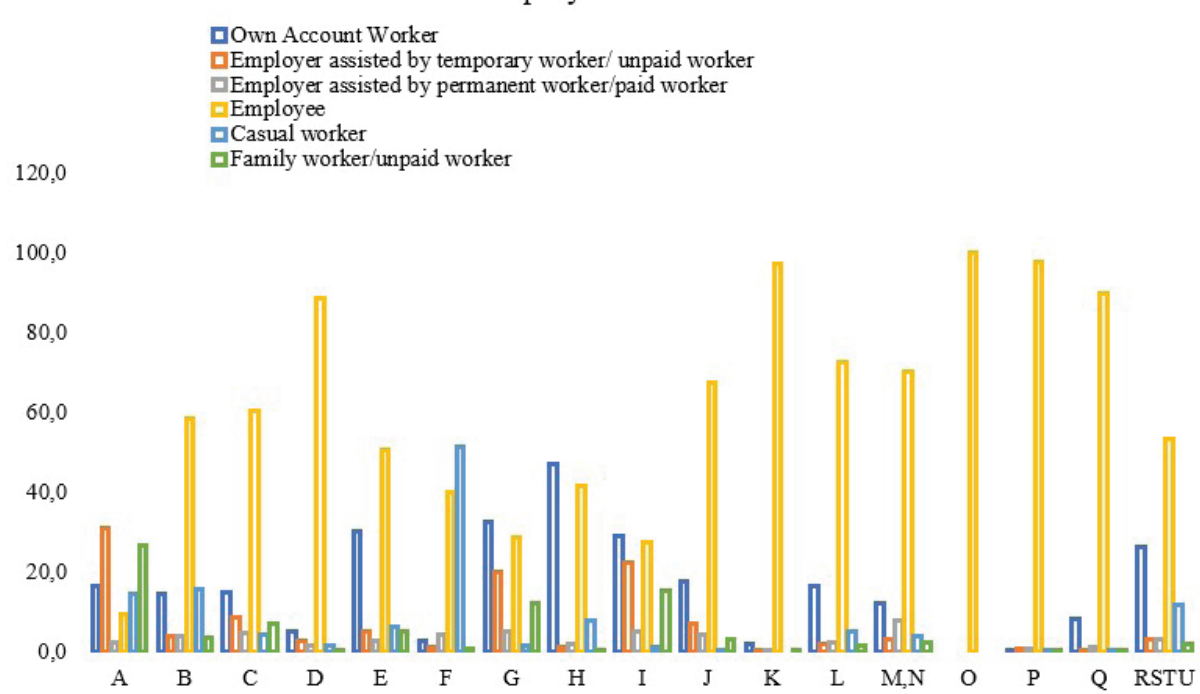

Figure 4: Employment Status 
and government expenditure. In situations of economic growth that are VUCA (Volatility, Uncertainty, Complexity, and Ambiguity) in the future, graphic structures such as those depicted in Appendix 2 can be unstable and have a significant impact from microstructures to macroeconomics.

\section{Conclusions}

Economic sectors are formed from the middle to lower classes where the center to smaller economic groups have a lot of impact on the rate of economic growth. Therefore, government attention in the form of government expenditure and investment must be maximized on the industrial cogs for the middle class and below. Curves that show people's dependence on the state give a negative signal if, at any time, the economic conditions and the country's conditions experience economic confusion.

It is the primary concern for the government to create a conducive and specific economic environment so that the problem of income inequality can be resolved. Government expenditure needs to be redesigned, not only predominantly to cover social security, but also needs further efforts so that it is optimally absorbed for the wheels of a potential economy driven by the middle-class (i.e., natural revenue). The income inequality that was felt was caused, among other factors, by the amount of the budget that was absorbed to finance employees who work under the government and the ministry. The middle-class is working in the A and $\mathrm{G}$ industries. Appendix 3 shows the distribution of most economic actors.

\section{References}

Adelman, I., \& Morris, C. T. (1973). Economic growth and social equity in developing countries. 27(September). 329345. Department of Economics, Delhi School of Economics, University of Delhi; Springer. https://www.jstor.org/ stable/29793615

Adriana, D. (2014). Revisiting the Relationship between Unemployment Rates and Shadow Economy. A TodaYamamoto Approach for the Case of Romania. Procedia Economics and Finance, 10(14), 227-236. https://doi. org/10.1016/s2212-5671(14)00297-4

Afidchao, M. M., Musters, C. J. M., Wossink, A., Balderama, O. F., \& De Snoo, G. R. (2014). Analysing the farm level economic impact of GM corn in the Philippines. NJAS - Wageningen Journal of Life Sciences, 70(December), 113-121. https://doi. org/10.1016/j.njas.2014.05.008

Andreas, D. (2018). BPS: 7 Million Unemployed Indonesians, Most Vocational School Graduates - Tirto.ID. Retrieved April 6, 2019, from: https://bit.ly/36EJ1LP

Arnold, L. G. (2000). Stability of the market equilibrium in Romer's model of endogenous technological change: A complete characterization. Journal of Macroeconomics, 22(1), 69-84. https://doi.org/10.1016/S0164-0704(00)00123-3

Birčiaková, N., Stávková, J., \& Antošová, V. (2014). The Impact of Economic Development in the Czech Republic on the Income Inequality between Groups of Households. Procedia Economics and Finance, 12(March), 57-65. https://doi.org/10.1016/s22125671(14)00320-7

Blundell, R., Joyce, R., Norris Keiller, A., \& Ziliak, J. P. (2018). Income inequality and the labour market in Britain and the US. Journal of Public Economics, 162(June), 48-62. https://doi. org/10.1016/j.jpubeco.2018.04.001

Bouwmeester, M. C., \& Scholtens, B. (2017). Cross-border investment expenditure spillovers in European gas infrastructure. Energy Policy, 107(July), 371-380. https://doi. org/10.1016/j.enpol.2017.05.010

Candemir, A., \& Zalluhoglu, A. E. (2011). The effect of marketing expenditures during financial crisis: The case of Turkey. Procedia - Social and Behavioral Sciences, 24, 291-299. https://doi.org/10.1016/j.sbspro.2011.09.105

Chin, W. (1998). The partial least squares approach to structural equation modeling. Modern Methods for Business Research, 295(2), 295-336. https://doi.org/10.1016/j.aap.2008.12.010

Davidson, P. (2011). Post Keynesian macroeconomic theory. Cheltenham, UK: Edward Elgar Publishing.

Di-Domenico, S. I., \& Fournier, M. A. (2014). Socioeconomic status, income inequality, and health complaints: A basic psychological needs perspective. Social Indicators Research, 119(3), 1679-1697. https://doi.org/10.1007/s11205-013-0572-8

Dinh, D. V. (2020). Optimal Inflation Threshold and Economic Growth: Ordinal Regression Model Analysis. Journal of Asian Finance, Economics and Business, 7(5), 91-102. https://doi. org/10.13106/jafeb.2020.vol7.no5.091

Elshamy, H. (2013). The Relationship Between Unemployment and Output in Egypt. Procedia - Social and Behavioral Sciences, 81(june), 22-26. https://doi.org/10.1016/j.sbspro.2013.06.381

Félix, D. (1996). La globalización financiera contra el libre comercio: defensa del impuesto Tobin. Investigación Económica, 56(217), 151-230. https://www.jstor.org/stable/42779494

Fornell, C., \& Larcker, D. F. (1981). Structural equation models with unobservable variables and measurement error: Algebra and statistics. Journal of Marketing Research, 18(3), 382-388. https://doi.org/10.2307/3150980

Gächter, S., Mengel, F., Tsakas, E., \& Vostroknutov, A. (2017). Growth and inequality in public good provision. Journal of Public Economics, 150(June), 1-13. https://doi.org/10.1016/j. jpubeco.2017.03.002

Ghoshray, A., Ordóñez, J., \& Sala, H. (2016). Euro, crisis and unemployment: Youth patterns, youth policies? Economic Modelling, 58(November), 442-453. https://doi.org/10.1016/j. econmod.2016.05.017

Ghozali, I. (2013). Multivariate Analysis Application with IBM and SPSS Programs. In multivariate analysis application 
with the IBM SPSS program 19, 1-113. Semarang, Indonesia: Universitas Diponoegoro [Indonesian]

Goschin, Z. (2015). Territorial Inequalities and Economic Growth in Romania. A Multi-factor Approach. Procedia Economics and Finance, 22(November), 690-698. https://doi.org/10.1016/ s2212-5671(15)00285-3

Guerrazzi, M.(2015). Animal spirits, investment and unemployment: An old Keynesian view of the Great Recession. EconomiA, 16(3), 343v358. https://doi.org/10.1016/j.econ.2015.09.002

Hair, J. F., Henseler, J., Dijkstra, T. K., \& Sarstedt, M. (2014). Common beliefs and reality about partial least squares: comments on Rönkkö and Evermann. Organizational Research Methods, 17(2), 182-209. https://doi.org/10.1177/1094428114526928

Halvarsson, D., Korpi, M., \& Wennberg, K. (2018). Entrepreneurship and income inequality. Journal of Economic Behavior and Organization, 145(January), 275-293. https://doi. org/10.1016/j.jebo.2017.11.003

Han, J., Zhao, Q., \& Zhang, M. (2015). China's income inequality in the global context. Perspectives in Science, 7(March), 24-29. https://doi.org/10.1016/j.pisc.2015.11.006

Haryanto, T. P. (2013). Effects of Government Expenditures on Regency / City Economic Growth in Central Java Province in 2007-2011.. Economics Development Analysis Journal, 2(3), 106-118. https://doi.org/10.15294/edaj.v2i3.1989

Hassan, S. A., Zaman, K., \& Gul, S. (2015). The Relationship between Growth-Inequality-Poverty Triangle and Environmental Degradation: Unveiling the Reality. Arab Economic and Business Journal, 10(1), 57-71. https://doi. org/10.1016/j.aebj.2014.05.007

Hidayat, M. (2014). Inequality across districts and cities in the Riau. Economic Journal of Emerging Markets, 6(1), 106-118. http://dx.doi.org/10.20885/ejem .vol6.iss2.art4

Hirschman, E. C., \& Holbrook, M. B. (1992). Postmodern Consumer Research. In: Postmodern Consumer Research, Volume 1. Association for Consumer Research.

Hoff, K. (2000). Beyond Rosenstein-Rodan: the modern theory of coordination problems in development. Proceedings of the Annual World Bank Conference on Development Economics (pp. 145-188). World Bank Publications, Washington, DC.

Jhingan, M. L. (1996). Economic Development Planning. Jakarta, Indonesia: Rajawali Pers. [Indonesian]

Khodeir, A. N. (2016). The Relationship between the Generation of Electricity from Renewable Resources and Unemployment: An Empirical Study on the Egyptian Economy. Arab Economic and Business Journal, 11(1), 16-30. https://doi.org/10.1016/j. aebj.2015.10.003

Kim, D. (2016). The associations between US state and local social spending, income inequality, and individual all-cause and cause-specific mortality: The National Longitudinal Mortality Study. Preventive Medicine, 84, 62-68. https://doi. org/10.1016/j.ypmed.2015.11.013
King, R., \& Rebelo, S. (1988). Business cycles with endogenous growth. Journal of Monetary Economics, 21, 195-232

Kudasheva, T., Kunitsa, S., \& Mukhamediyev, B. (2015). Effects of Access to Education and Information-communication Technology on Income Inequality In Kazakhstan. Procedia Social and Behavioral Sciences, 191(June), 940-947. https:// doi.org/10.1016/j.sbspro.2015.04.459

Kuncoro, A. (2006). Corruption and business uncertainty in Indonesia. ASEAN Economic Bulletin, 23(1).11-30.

Kuznets, S. (1955). Economic growth and income inequality. The American Economic Review, 45(1), 1-28.

Lavrinovicha, I., Lavrinenko, O., \& Teivans-Treinovskis, J. (2015). Influence of Education on Unemployment Rate and Incomes of Residents. Procedia - Social and Behavioral Sciences, 174(February), 3824-3831. https://doi.org/10.1016/j. sbspro.2015.01.1120

Li, Q., \& Hu, J. (2015). Military Expenditure and Unemployment in China1. Procedia Economics and Finance, 30(15), 498-504. https://doi.org/10.1016/s2212-5671(15)01247-2

Luong, T. T. H., Nguyen, T. M., \& Nguyen, T. A. N. (2020). Rule of Law, Economic Growth and Shadow Economy in Transition Countries. Journal of Asian Finance, Economics and Business, 7(4), 145-154. https://doi.org/10.13106/jafeb.2020.vol7. no4.145

Lyubimov, I. (2017). Income Inequality Revisited 60 Years Later: Piketty vs Kuznets. Economic Policy (in Russian), 11(1), 2742. https://doi.org/10.18288/1994-5124-2016-1-03

Mihaiu, D. M., \& Opreana, A. (2013). The Analysis of the Relationship between the Level of the Public Expenditure for Investments and de Degree of Development of the Society in Romania. Procedia Economics and Finance, 6(13), 654-661. https://doi.org/10.1016/s2212-5671(13)00185-8

Myrdal, G., \& Sitohang, P. (1957). Economic theory and underdeveloped regions. London, UK: Gerald Duckworth \& Co.

Neary, J. P. (1981). On the Harris-Todaro model with intersectoral capital mobility. Economica, 48(191), 219-234.

Nguyen, H. H. (2019). The Role of State Budget Expenditure on Economic Growth: Empirical Study in Vietnam. The Journal of Asian Finance, Economics and Business, 6(3), 81-89. https:// doi.org/10.13106/jafeb.2019.vol6.no3.81

Nguyen, H. H. (2020). Impact of Foreign Direct Investment and International Trade on Economic Growth: Empirical Study in Vietnam. Journal of Asian Finance, Economics and Business, 7(3), 323-331. https://doi.org/10.13106/jafeb.2020.vol7. no3.323

O’Campo, P., Molnar, A., Ng, E., Renahy, E., Mitchell, C., Shankardass, K., Muntaner, C. (2015). Social welfare matters: A realist review of when, how, and why unemployment insurance impacts poverty and health. Social Science and Medicine, 132(May), 88-94. https://doi.org/10.1016/j. socscimed.2015.03.025 
Omri, A., \& kahouli, B. (2014). The nexus among foreign investment, domestic capital and economic growth: Empirical evidence from the MENA region. Research in Economics, 68(3), 257-263. https://doi.org/10.1016/j.rie.2013.11.001

PP No. 8 Tahun. (2007). Republic of Indonesia Government Regulation Number 8 of 2007. Retrieved April 6, 2019, from: https://bit.ly/3d0SfEv

Putra, A. H. P. K., Said, S., \& Hasan, S. (2017). Implication Of External And Internal Factors Of Mall Consumers In Indonesia To Impulsive Buying Behavior. International Journal of Business Accounting and Management, 2(4), 1-10.

Raišienè, A. G., Bagdonienè, J., \& Bilan, Y. (2014). InterInstitutional Interaction Results: The Effect of EU Programs on the Reduction of Long-term Unemployment. Procedia Economics and Finance, 16(May), 641-650. https://doi. org/10.1016/s2212-5671(14)00852-1

Ram, R. (1982). International inequality in the basic needs indicators. Journal of Development Economics, 10(1), 113-117. https://doi.org/10.1016/0304-3878(82)90059-1

Ram, R. (1992). Intercountry inequalities in income and basic-needs indicators: A recent perspective. World Development, 20(6), 899-905. https://doi.org/10.1016/0305-750X(92)90059-5

Romer, P. M. (1994). The origins of endogenous growth. Journal of Economic Perspectives, 8(1), 3-22. https://doi.org/10.1257/ jep.8.1.3

Roşoiu, I. (2015). The Impact of the Government Revenues and Expenditures on the Economic Growth. Procedia Economics and Finance, 32(15), 526-533. https://doi.org/10.1016/S22125671(15)01428-8

Saari, M. Y., Dietzenbacher, E., \& Los, B. (2015). Sources of Income Growth and Inequality Across Ethnic Groups in Malaysia, 1970-2000. World Development, 76(December), 311-328. https://doi.org/10.1016/j.worlddev.2015.07.015

Sadikova, M., Faisal, F., \& Resatoglu, N. G. (2017). Influence of energy use, foreign direct investment and population growth on unemployment for Russian Federation. Procedia Computer Science, 120, 706-711. https://doi.org/10.1016/j. procs.2017.11.299

Sadiku, M., Ibraimi, A., \& Sadiku, L. (2015). Econometric Estimation of the Relationship between Unemployment Rate and Economic Growth of FYR of Macedonia. Procedia Economics and Finance, 19(15), 69-81. https://doi.org/10.1016/ s2212-5671(15)00009-x

Sargent, T. J. (2009). Dynamic macroeconomic theory. Cambridge, MA: Harvard University Press.

Shao, C., Meng, X., Cui, S., Wang, J., \& Li, C. (2016). Incomerelated health inequality of migrant workers in China and its decomposition: An analysis based on the 2012 China Laborforce Dynamics Survey data. Journal of the Chinese Medical
Association, 79(10), 531-537. https://doi.org/10.1016/j. jcma.2016.02.009

Shen, W., Yang, S. C. S., \& Zanna, L. F. (2018). Government spending effects in low-income countries. Journal of Development Economics, 133(November), 201-219. https:// doi.org/10.1016/j.jdeveco.2018.02.005

Strat, V. A., Davidescu, A., \& Paul, A. M. (2015). FDI and The Unemployment - A Causality Analysis for the Latest EU Members. Procedia Economics and Finance, 23(October), 635-643. https://doi.org/10.1016/S2212-5671(15)00448-7

Sukarno, P. A. (2019). Indonesia Offers Digital Economic Investment Opportunities and $10 \mathrm{New}$ Bali. Retrieved April 6, 2019, from: https://bit.ly/3c7w4LC

Sukirno, S. (2003). Introduction to Microeconomic Theory. Jakarta, Indonesia: PT. Raja Grafindo persada [Indonesian]

Sukirno, S. (2004). Macroeconomic theory: The Introduction. Jakarta, Indonesia: PT Raja Grafindo Persada.[Indonesian]

Szkorupová, Z. (2014). A Causal Relationship between Foreign Direct Investment, Economic Growth and Export for Slovakia. Procedia Economics and Finance, 15, 123-128. https://doi. org/10.1016/S2212-5671(14)00458-4

Tjoe, Y. (2018). How severe is economic inequality in Indonesia? Retrieved April 5, 2019, from: https://bit.ly/3gmVCrp

Trejo García, J. C., Rivera Hernández, E. C., \& Ríos Bolívar, H. (2017). Analysis of the hysteresis of unemployment in Mexico in the face of macroeconomic shocks. Contaduria $y$ Administración, 62(4), 1249-1269. https://doi.org/10.1016/j. cya.2017.06.013

Widyanita. (2017). Indonesia's Economic Inequality Rank 4| Katadata News. Retrieved April 5, 2019, from: https://bit. ly/2TB630t

www.bbc.com. (2014). Inequality of income has an impact on economic growth - BBC News Indonesia. Retrieved April 5, 2019, from: https://bbc.in/3eb1u4W

www.databoks.katadata.co.id. (2017). Only 42\% of Workers Work in Formal Activities | Databoks. Retrieved April 6, 2019, from: https://bit.ly/2LT9GL4

www.kemenkeu.go.id. (2018). APBN 2018 Information. Retrieved April 5, 2019, from: https://bit.ly/3c0AQKH

www.kemenprin.go.id. (2018). Kemenperin: Get rid of Investment Barriers. Retrieved April 6, 2019, from: https://bit.ly/2X1vHO0

www.nasional.kontan.co.id. (2010). Six Obstacles to Investment in Indonesia. Retrieved April 6, 2019, from: https://bit. ly/3cZFXMo

www.republika.co.id. (2018). Japan Complains of Investment Barriers in Indonesia | Republika Online. Retrieved April 6, 2019, from: https://bit.ly/3d3gRw9

www.worldbank.org. (2015). Widespread Inequality in Indonesia. Retrieved April 5, 2019, from: https://bit.ly/2A1VTzb 
Appendix 1: Resume of Data Materials

\begin{tabular}{|c|c|c|c|c|c|}
\hline Year & $\begin{array}{c}\text { Investment } \\
\text { (in Million } \\
\text { Rupiahs) }\end{array}$ & $\begin{array}{c}\text { Government } \\
\text { Expenditure } \\
\text { (In million rupiah) }\end{array}$ & $\begin{array}{c}\text { Economics } \\
\text { Growth } \\
\text { (in Percent) }\end{array}$ & $\begin{array}{c}\text { Unemployment } \\
\text { (in Percent) }\end{array}$ & $\begin{array}{c}\text { Inequality } \\
\text { Income } \\
\text { (In Percent) }\end{array}$ \\
\hline 2003 & $13.690,78$ & 49.085 .485 .600 .000 & 4,8 & 9,01 & 0,244 \\
\hline 2004 & $17.092,91$ & 54.758 .918 .128 .000 & 3,9 & 9,20 & 0,303 \\
\hline 2005 & $31.479,24$ & 61.719 .839 .959 .000 & 5,8 & 10,09 & 0,346 \\
\hline 2006 & $19.589,80$ & 81.799 .148 .671 .000 & 4,8 & 9,68 & 0,335 \\
\hline 2007 & $34.878,70$ & 80.239 .537 .115 .789 & 5,7 & 8,58 & 0,332 \\
\hline 2008 & $20.363,20$ & 116.127 .432 .588 .942 & 5,8 & 7,59 & 0,359 \\
\hline 2009 & $37.798,90$ & 146.193 .922 .129 .909 & 5,9 & 7,23 & 0,376 \\
\hline 2010 & $60.574,97$ & 145.259 .539 .876 .708 & 6,8 & 6,61 & 0,363 \\
\hline 2011 & $75.953,52$ & 169.266 .037 .596 .500 & 6,1 & 6,43 & 0,378 \\
\hline 2012 & $92.136,19$ & 230.312 .131 .024 .567 & 6,3 & 5,37 & 0,379 \\
\hline 2013 & $127.846,63$ & 247.286 .175 .263 .282 & 6,1 & 5,16 & 0,38 \\
\hline 2014 & $156.026,11$ & 276.048 .170 .080 .868 & 5,5 & 5,02 & 0,379 \\
\hline 2015 & $179.402,41$ & 303.378 .727 .360 .023 & 5,7 & 5,56 & 0,364 \\
\hline 2016 & $216.295,47$ & 310.542 .927 .441 .006 & 5,3 & 5,02 & 0,36 \\
\hline 2017 & $129.770,19$ & 377.420 .211 .667 .339 & 5,2 & 4,97 & 0,36 \\
\hline 2018 & $328.554,02$ & 397.290 .251 .346 .567 & 5,3 & 4,70 & 0,357 \\
\hline
\end{tabular}

Appendix 2: Correlation Between Variables

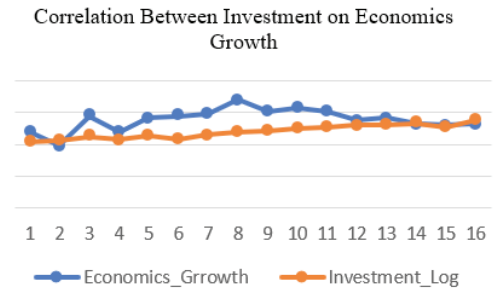

(a)

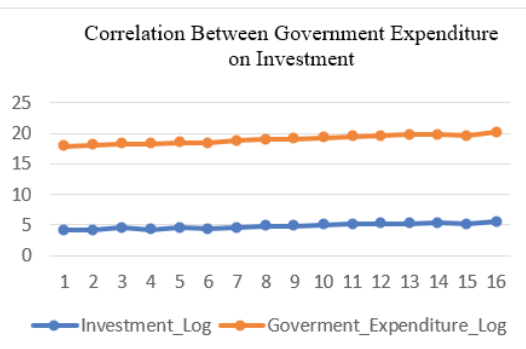

(d)

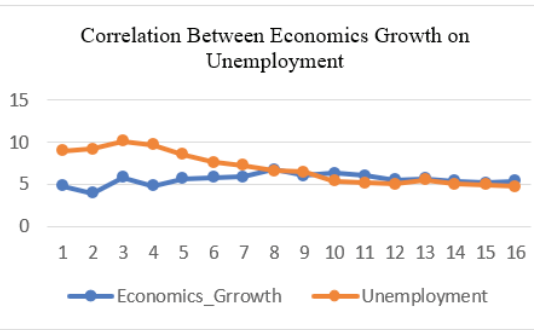

(b)

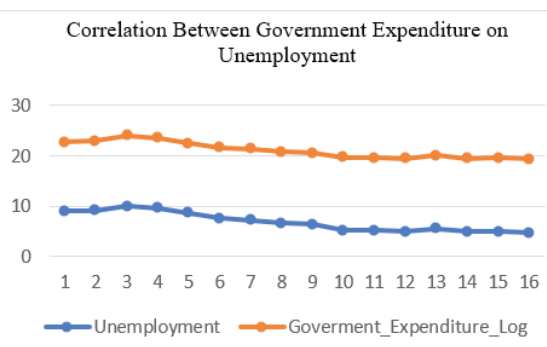

(e)

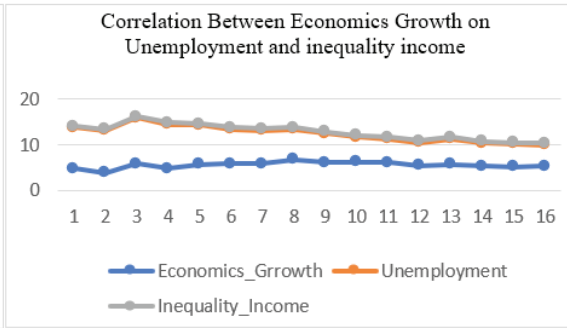

(c)

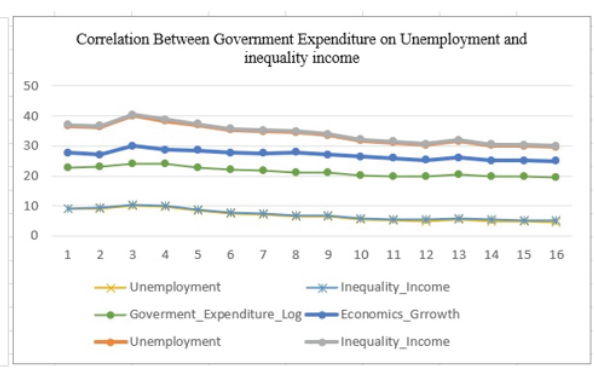

(f) 
Appendix 3: Percentage Allocation of Population 15 Years of Ages by Main Employement Status and Main Industry 2019

\begin{tabular}{|c|c|c|c|c|c|c|c|c|c|c|c|c|c|c|c|c|c|c|}
\hline \multirow{2}{*}{\multicolumn{2}{|c|}{$\begin{array}{c}\text { Main } \\
\text { Employment } \\
\text { Status }\end{array}$}} & \multicolumn{17}{|c|}{ Main Industry (\%) } \\
\hline & & A & B & C & D & $\mathbf{E}$ & $\mathbf{F}$ & G & H & I & $J$ & K & $\mathbf{L}$ & $\mathbf{M}, \mathbf{N}$ & O & $\mathbf{P}$ & $\mathbf{Q}$ & RSTU \\
\hline \multicolumn{2}{|c|}{$\begin{array}{l}\text { Main } \\
\text { Employment } \\
\text { Status }\end{array}$} & 16,3 & 14,6 & 14,8 & 5,2 & 30,2 & 2,6 & 32,6 & 46,8 & 29,1 & 17,6 & 1,8 & 16,5 & 12,2 & & 0,6 & 8,1 & 26,4 \\
\hline \multicolumn{2}{|c|}{$\begin{array}{l}\text { Own Account } \\
\text { Worker }\end{array}$} & 30,9 & 3,9 & 8,6 & 2,6 & 5,2 & 1,3 & 20,0 & 1,2 & 22,4 & 7,1 & 0,3 & 2,1 & 3,2 & & 0,6 & 0,5 & 3,1 \\
\hline \multicolumn{2}{|c|}{$\begin{array}{l}\text { Employer } \\
\text { assisted by } \\
\text { temporary } \\
\text { worker/ } \\
\text { unpaid worker }\end{array}$} & 2,4 & 4,0 & 4,7 & 1,6 & 2,6 & 4,3 & 5,2 & 2,1 & 5,0 & 4,2 & 0,5 & 2,3 & 7,9 & & 0,8 & 1,3 & 3,3 \\
\hline \multicolumn{2}{|c|}{$\begin{array}{l}\text { Employer } \\
\text { assisted by } \\
\text { permanent } \\
\text { worker/ } \\
\text { paid worker }\end{array}$} & 9,4 & 58,4 & 60,4 & 88,6 & 50,7 & 40,0 & 28,4 & 41,5 & 27,4 & 67,5 & 97,3 & 72,6 & 70,3 & 100 & 97,5 & 89,6 & 53,4 \\
\hline \multicolumn{2}{|c|}{ Employee } & 14,6 & 15,5 & 4,5 & 1,5 & 6,2 & 51,2 & 1,5 & 7,9 & 1,0 & 0,5 & & 5,0 & 4,0 & & 0,1 & 0,2 & 11,7 \\
\hline \multicolumn{2}{|c|}{ Casual worker } & 26,5 & 3,6 & 7,1 & 0,5 & 5,1 & 0,7 & 12,2 & 0,5 & 15,2 & 3,1 & 0,1 & 1,5 & 2,4 & & 0,3 & 0,4 & 2,1 \\
\hline \multicolumn{2}{|c|}{$\begin{array}{l}\text { Family worker/ } \\
\text { unpaid worker }\end{array}$} & 16,3 & 14,6 & 14,8 & 5,2 & 30,2 & 2,6 & 32,6 & 46,8 & 29,1 & 17,6 & 1,8 & 16,5 & 12,2 & & 0,6 & 8,1 & 26,4 \\
\hline \multicolumn{19}{|c|}{ Info main Industry and Total Employment Status (In Person) } \\
\hline A & \multicolumn{8}{|c|}{ Agriculture, Forestry, and Fishing } & \multicolumn{10}{|c|}{35.703 .074} \\
\hline B & \multicolumn{8}{|c|}{ Mining and Quarrying } & \multicolumn{10}{|c|}{1.454 .256} \\
\hline C & \multicolumn{8}{|c|}{ Manufacturing } & \multicolumn{10}{|c|}{18.251 .456} \\
\hline $\mathrm{D}$ & \multicolumn{8}{|c|}{ Electricity and Gas } & \multicolumn{10}{|c|}{338.447} \\
\hline E & \multicolumn{8}{|c|}{$\begin{array}{l}\text { Water Supply; Sewerage, Waste Management, and } \\
\text { Remediation Activities }\end{array}$} & \multicolumn{10}{|c|}{471.067} \\
\hline $\mathrm{F}$ & \multicolumn{8}{|c|}{ Construction } & \multicolumn{10}{|c|}{8.300 .297} \\
\hline G & \multicolumn{8}{|c|}{$\begin{array}{l}\text { Wholesale and Retail Trade; Repair of Motor } \\
\text { Vehicles and Motorcycles }\end{array}$} & \multicolumn{10}{|c|}{23.073 .515} \\
\hline $\mathrm{H}$ & \multicolumn{8}{|c|}{ Transportation and Storage } & \multicolumn{10}{|c|}{5.398 .582} \\
\hline I & Accomr & odation & and & ood $S$ & ervice & Activi & ties & & & & & & 7.66 & 236 & & & & \\
\hline $\mathrm{J}$ & Informa & on and & Comı & nunica & tion & & & & & & & & 894 & 673 & & & & \\
\hline $\mathrm{K}$ & Financi & and In & Isuran & ce Act & vities & & & & & & & & 1.79 & .913 & & & & \\
\hline L & Real Es & ate Acti & ivities & & & & & & & & & & 389 & 925 & & & & \\
\hline $\mathrm{M}, \mathrm{N}$ & Busines & Activit & ies & & & & & & & & & & 1.66 & .791 & & & & \\
\hline O & $\begin{array}{l}\text { Public } A \\
\text { Social } \$\end{array}$ & $\begin{array}{l}\text { Iministr } \\
\text { Curity }\end{array}$ & ration & and $\mathrm{D}$ & efence & Com & pulsor & & & & & & 4.68 & .280 & & & & \\
\hline$P$ & Educati & & & & & & & & & & & & 6.06 & .878 & & & & \\
\hline Q & Human & lealth a & and Sc & cial W & ork Ac & tivities & & & & & & & 1.84 & 460 & & & & \\
\hline RSTU & Other S & rvices & Activit & & & & & & & & & & 6.00 & .100 & & & & \\
\hline
\end{tabular}


Appendix 4: Regression Test

\begin{tabular}{|c|c|c|c|c|c|c|}
\hline & $\beta$ & Std. Error & Beta & $\mathrm{T}$ & P-Value & Info \\
\hline (Constant) & -2.427 & 1.038 & & -2.338 & $0.039<0.05$ & Supported \\
\hline Economic Growth $\rightarrow$ Inequality income & 0.026 & 0.008 & 0.502 & 3.174 & $0.009<0.01$ & Supported \\
\hline Government Expenditure $\rightarrow$ Inequality Income & 0.184 & 0.075 & 1.603 & 2.451 & $0.032<0.05$ & Supported \\
\hline Unemployment $\rightarrow$ Inequality Income & 0.166 & 0.055 & 0.985 & 2.112 & $0.022<0.05$ & Supported \\
\hline Investment $\rightarrow$ inequality income & -0.019 & 0.035 & -0.235 & -0.547 & $0.596>0.05$ & Not Supported \\
\hline \multicolumn{7}{|l|}{$\mathrm{R}$-Square $=0.874$} \\
\hline \multicolumn{7}{|l|}{$\mathrm{F}$ test $=8.870 ; \mathrm{sig} 0.00$} \\
\hline \multicolumn{7}{|l|}{ Kolomogorov Smirnov test $=0.958>0.05$} \\
\hline \multicolumn{6}{|c|}{ Sobel Test } & Info \\
\hline $\begin{array}{l}\text { Government Expenditure - Economic Growth } \\
\text { - Inequality income }\end{array}$ & $\begin{array}{l}0.082 \\
0.024\end{array}$ & $\begin{array}{l}0.022 \\
0.008\end{array}$ & - & 2.337 & $0.019<0.05$ & Supported \\
\hline $\begin{array}{l}\text { Government Expenditure - Unemployment - } \\
\text { Inequality income }\end{array}$ & $\begin{array}{l}0.182 \\
0.012\end{array}$ & $\begin{array}{l}0.022 \\
0.013\end{array}$ & - & 0.896 & $0.370>0.05$ & Not Supported \\
\hline $\begin{array}{l}\text { Investment - Economic Growth - Inequality } \\
\text { Income }\end{array}$ & $\begin{array}{l}0.052 \\
0.026\end{array}$ & $\begin{array}{l}0.009 \\
0.009\end{array}$ & - & 2.520 & $0.011<0.05$ & Supported \\
\hline $\begin{array}{l}\text { Investment - Unemployment - Inequality } \\
\text { Income }\end{array}$ & $\begin{array}{c}0.051 \\
-0.006\end{array}$ & $\begin{array}{l}0.016 \\
0.009\end{array}$ & - & -0.643 & $0.520>0.05$ & Not Supported \\
\hline
\end{tabular}

